
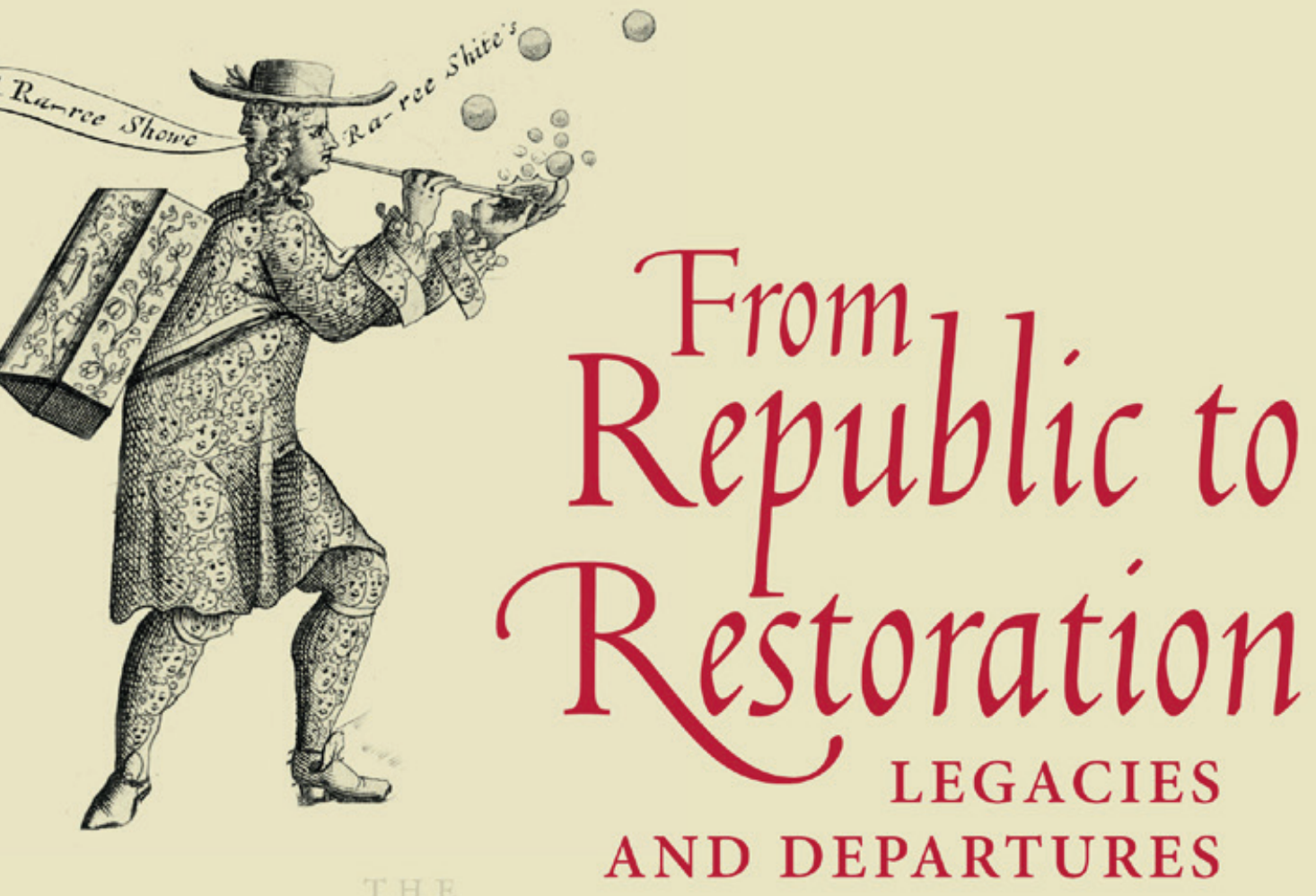

READIE \& EASIE

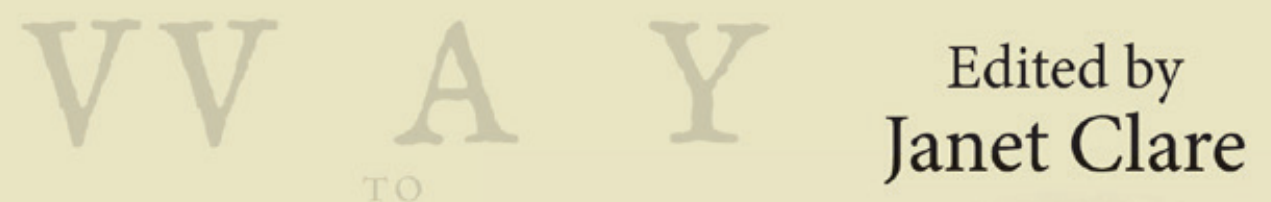
E S T A B L I S H Free

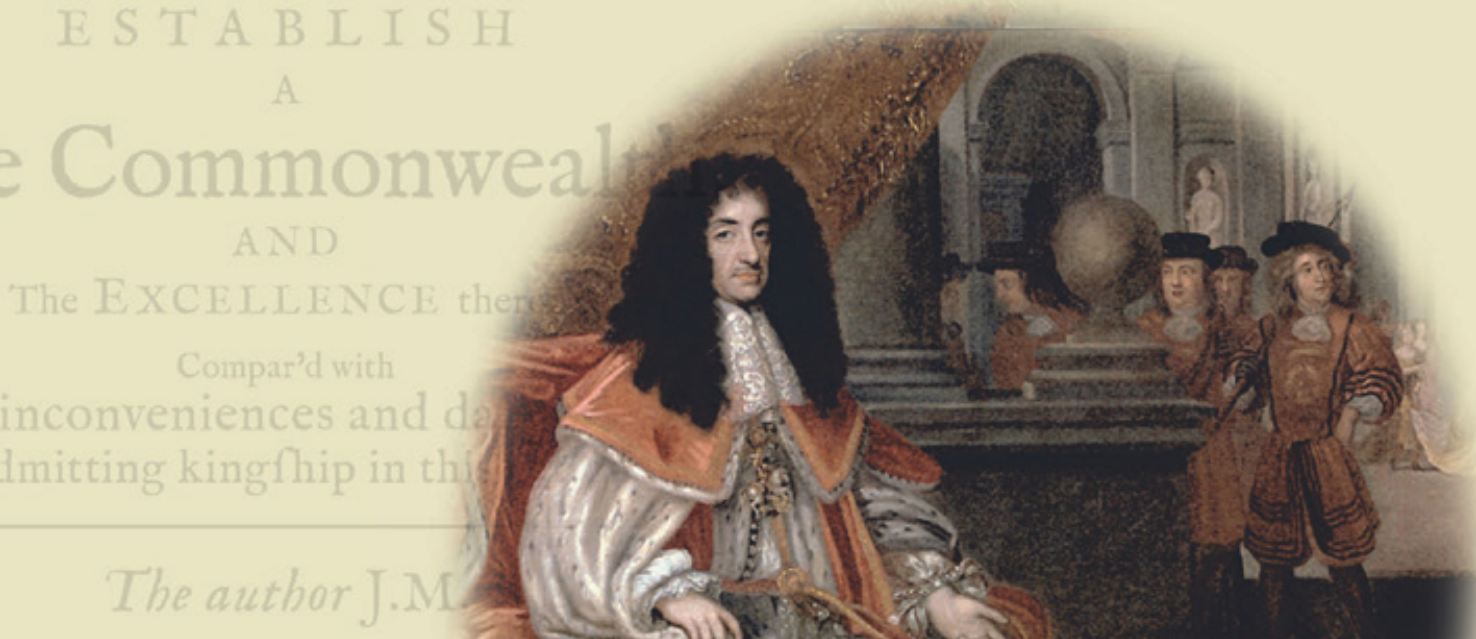

The inconveniences and $c$ readmitting kinglhip in this

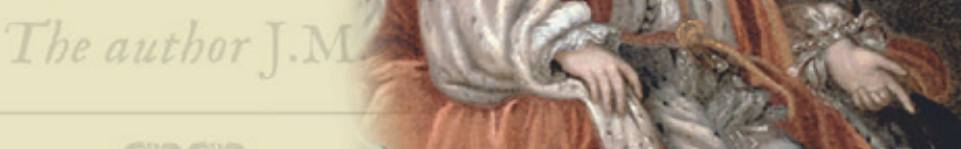




\section{From Republic to Restoration}

\section{MANCHESTER 1824}

Manchester University Press 
Janet Clare - 9781526107510 Downloaded from manchesterhive.com at 04/26/2023 11:36:03AM via free access 


\section{From Republic to Restoration}

Legacies and departures

Edited by Janet Clare

Manchester University Press 
While copyright in the volume as a whole is vested in Manchester University Press, copyright in individual chapters belongs to their respective authors, and no chapter may be reproduced wholly or in part without the express permission in writing of both author and publisher.

Published by Manchester University Press

Altrincham Street, Manchester Mi 7JA

www.manchesteruniversitypress.co.uk

British Library Cataloguing-in-Publication Data

A catalogue record for this book is available from the British Library

ISBN 978 o 719089688 hardback

First published 2018

The publisher has no responsibility for the persistence or accuracy of URLs for any external or third-party internet websites referred to in this book, and does not guarantee that any content on such websites is, or will remain, accurate or appropriate.

Typeset by Out of House Publishing 